\title{
An Economic Analysis of Third Party Litigation Funding
}

\author{
CHEN Wenjing \\ East China University of Political Science and Law, Shanghai, China
}

\begin{abstract}
Third party litigation funding (TPLF) is one of the most innovative trends in litigation funding industry. In a TPLF contract, an external investor (the third party funder) financially supports a litigant to cover litigation expenses. If the claim is finally successful, a share of recoveries will come to the funder in return. On the other hand, the third party funder will receive no compensation if the plaintiff loses the suit. Up till now, in some common law jurisdictions (e.g., Australia, the UK, and the U.S.), TPLF has been legally accepted and develops rapidly. Meanwhile, concerns about the use of TPLF have also been raised. For example, whether TPLF will encourage frivolous suits and unmeritorious claims; and whether the use of TPLF will be socially desirable. In this article, a basic economic model of TPLF will be built firstly. Then, analysis based on this model will be delivered and further social externalities brought by the use of TPLF will also be investigated. Finally, through an economic analysis, it is concluded that TPLF is generally social desirable but regulations should be imposed.
\end{abstract}

Keywords: third party litigation funding, economic model, frivolous cases, social desirability

\section{Introduction}

The most recent development in litigation funding is third party litigation funding (TPLF) ${ }^{1}$, in which a third party funder funds a litigant to cover litigation costs in a civil lawsuit. In recent years, as a growing industry, the TPLF has drawn lots of attention from policy-makers, legal professions, and potential litigation parties. Actually, most of the opinions hold that TPLF can be helpful to solve funding problems with civil litigation, but it should be approached cautiously (Kalajdzic, Cashman, \& Longmoore, 2013). Up till now, TPLF has notably spread in Australia, some European Jurisdictions (Austria, Germany, Ireland, and the UK) (Vogenauer \& Tulibacka, 2010) and the US to finance civil litigation (U.S. Chamber Institute for Legal Reform, 2009).

Although TPLF has received lots of positive comments that it facilitates the "access to justice" for impecunious individuals, opponents suppose that TPLF can "pose thorny ethical issues" (e.g., increase the number of frivolous litigation, claims without merits, and gold mining litigation) (Thomson Reuters, 2011). In this article, an economic analysis will be conduct to deeply examine the working mechanism of TPLF. For example, incentives for parties in TPLF (the third party funder and the funded litigant) will be investigated through an economic-based approach. When the economic analysis is carried out, rules for cost-shifting under

CHEN Wenjing, Doctor of Law, assistant professor, Institute of BRICS Legal Studies of East China University of Political Science and Law, Shanghai, China.

${ }^{1}$ Strictly speaking, public funding and lawyer's funding are also within the scope of third party funding, because they also come from the outside. But in this article, TPLF excludes the public funding and funding by lawyers. It only refers to funding coming from an outside private investor who makes money from investing in lawsuits. 
American law (no cost-shifting) and English law (cost-shifting) will be taken into consideration. Based on the basic economic model, externalities brought by TPLF will be studied, and finally, it is concluded that certain regulations should be imposed on the use of TPLF to achieve social desirability.

\section{The Basic Economic Model for TPLF}

In this section, a basic economic model for TPLF will be built based on an assumption that all of claims brought by a litigant will definitely be judged in the court (Thomson Reuters, 2011). When the economic models are built, American rule (no cost-shifting) and English rule (cost-shifting) will be taken into consideration.

\section{Under American Rule (No Cost-Shifting)}

Firstly, we build an economic model for TPLF under American rule, where each party of a lawsuit bears their own legal costs. And the incentives for the funder and the litigant under this rule will be analyzed respectively through an economic-based way.

For the third party funder. The funder, who is in nature a profit maximizer, will be willing to financially assist a suit when the expected revenue from his investment is higher than the expected costs. Given that, the funder will cautiously evaluate the merit of the claim and the size of the claim, and furthermore estimate the potential proceeds (P) brought by the lawsuit (Thomson Reuters, 2011). Apart from that, the success rate of the case (S) needs to be considered as well (Calihan, Dent, \& Victor, 2004). And also, the funder and the plaintiff will contractually determine the share of proceeds (R) (e.g., $25 \%$ of the final proceeds) that the funder will be awarded after a favorable judgment is reached. The potential reward of the funder will definitely be proportionate to the (P) and $(\mathrm{S})$. In general, the final reward will be calculated like $\mathrm{E}\left(\mathrm{M}^{\prime}\right)=(\mathrm{P}) \times(\mathrm{S}) \times(\mathrm{R})$, which could be considered as the expected revenue for the funder.

The funder's expected costs E(C) are the plaintiff's legal expenses associated with the suit. Normally, the cost package may include the court's fees and the lawyer's fees. And under American rule, no adverse fees will be required if the plaintiff loses the suit. In fact, the third party funder will invest only if $E\left(M^{\prime}\right)>E(C)$.

Suppose the potential proceeds of a case are worth 100,000 Euro (P), the funder supposes that the (S) is $80 \%$, and the contractually determined $(\mathrm{R})$ is $30 \%$. The expected litigation costs $\mathrm{E}(\mathrm{C})$ is 20,000 Euro. In this case, $\mathrm{E}\left(\mathrm{M}^{\prime}\right)$ $=(P) \times(S) \times(R)=100,000 \times 80 \% \times 30 \%=24,000$ Euro $>20,000$ Euro. So, if $E\left(M^{\prime}\right)>E(C)$, the funder will invest.

For the plaintiff. From the perspective of the plaintiff, he will enter into a TPLF contract when the expected profits are increased by it. In the presence of the availability of TPLF, there are two scenarios for the plaintiff. In the first scenario, where TPLF is not provided, $\mathrm{E}(\mathrm{M})=(\mathrm{P}) \times(\mathrm{S})$, and the net proceeds are $\mathrm{E}(\mathrm{F})=\mathrm{E}(\mathrm{M})-\mathrm{E}(\mathrm{C})$. Only is the $\mathrm{E}(\mathrm{F})$ is greater than 0 , then plaintiff will choose to commence the suit.

In the second scenario, where the case is funded by TPLF, the cost-and-benefit analysis becomes more complicated. Under this circumstance, the plaintiff resorting to TPLF has to share $\mathrm{E}(\mathrm{M})$ with the funder, when the case is finally successful. In this case, the proceeds received by the third party funder are E(M'), while those got by the successful plaintiff are $\mathrm{E}\left(\mathrm{M}^{\prime}\right.$ '). ${ }^{2}$ As for the costs $\mathrm{E}(\mathrm{C})$, the plaintiff does not need to advance any money and bears no risk by turning to TPLF.

\footnotetext{
${ }^{2} \mathrm{E}(\mathrm{M})=\mathrm{E}\left(\mathrm{M}^{\prime}\right)+\mathrm{E}\left(\mathrm{M}^{\prime \prime}\right)^{\prime}$.
} 
Compared these two scenarios, the plaintiff is willing to resort to a third party funder only if $E\left(M{ }^{\prime \prime}\right)>E(F)$. Prior to further explanations in this regard, it is better to distinguish potential plaintiffs into two catalogues: The first type is the impecunious plaintiff who does not have money to commence a suit; the second type is the plaintiff who can financially afford litigation cost but he does not want to risk his own money and plans to resort to a third party funder.

For the first type, if the impecunious litigant did not turn to a funder, his/her expected proceeds $\mathrm{E}(\mathrm{M})$ would be 0 . If he/she sought help from an external funder, his/her $\mathrm{E}(\mathrm{C})$ would be 0 , and the $\mathrm{E}(\mathrm{M}$ ') would always be $>=$ 0 . Given that, for an indigent plaintiff, turning to TPLF is nothing to lose, but he/she has chances to earn proceeds.

For the plaintiff who is not under a budget constraint, we give a numerical example to investigate whether or not he/she will resort to TPLF. Assume the potential proceeds (the disputed value of a claim) are 100,000 Euro (P). The success rate of the case (S) is $80 \%$, and the contractually determined (R) with the funder is $30 \%$. The expected litigation costs $\mathrm{E}(\mathrm{C})$ is 20,000 Euro. In this case, if the plaintiff does not turn to a funder, the final proceeds for him/her will be: $\mathrm{E}(\mathrm{F})=\mathrm{E}(\mathrm{M})-\mathrm{E}(\mathrm{C})=(\mathrm{P}) \times(\mathrm{S})-\mathrm{E}(\mathrm{C})=100,000 \times 80 \%-20,000=80,000-$ $20,000=60,000$. On the other hand, if the plaintiff resort to a funder, the final proceeds for him/her will be: $\mathrm{E}\left(\mathrm{M}^{\prime \prime}\right)=\mathrm{E}(\mathrm{M})-\mathrm{E}\left(\mathrm{M}^{\prime}\right)=(\mathrm{P}) \times(\mathrm{S})-(\mathrm{P}) \times(\mathrm{S}) \times(\mathrm{R})=100,000 \times 80 \%-100,000 \times 80 \% \times 30 \%=80,000-$ $24,000=56,000$. The result shows that $\mathrm{E}\left(\mathrm{M}^{\prime \prime}\right)<\mathrm{E}(\mathrm{F})$, therefore, under this circumstance, the rational plaintiff who is not under a budget constraint will not choose to be funded by a third party funder.

In this example, it could be concluded that:

(1) For an impecunious plaintiff, turning to a third party funder is nothing to lose, and sometimes it will be profitable.

(2) For a non-impecunious plaintiff, turning to a third party funder only if $\mathrm{E}\left(\mathrm{M}^{\prime \prime}\right)>\mathrm{E}(\mathrm{F})$, that is $(\mathrm{P}) \times(\mathrm{S})$ $\mathrm{E}(\mathrm{C})>(\mathrm{P}) \times(\mathrm{S})-(\mathrm{P}) \times(\mathrm{S}) \times(\mathrm{R})$, which could be summarized like $(\mathrm{P}) \times(\mathrm{S})-\mathrm{E}(\mathrm{C})>(\mathrm{P}) \times(\mathrm{S}) \times[1-(\mathrm{R})]$, and then finally comes out like $(\mathrm{P}) \times(\mathrm{S}) \times(\mathrm{R})>\mathrm{E}(\mathrm{C})$. Therefore, the variable deciding whether a TPLF contract is favorable is the success rate of the case $(\mathrm{S})$. And other factors in the equation could be predicted in advance.

\section{Under English Rule (Cost-Shifting)}

The same with that under American rule, under English rule, a funder will choose to fund a case only if the $\mathrm{E}\left(\mathrm{M}^{\prime}\right)>\mathrm{E}(\mathrm{C})$. However, all litigation costs will be paid by the losing party under English rule. So, when the economic analysis is carried out, we should take this factor into consideration.

For the third party funder. Given English cost-shifting rule, if the funded litigant wins the case, the funder will bear no costs. But if the funded litigant loses, the total litigation costs paid by the funder will include the defendant's litigation fees. Under this circumstance, $\mathrm{E}(\mathrm{C})=\mathrm{E}(\mathrm{Cp})^{3}+\mathrm{E}(\mathrm{Cd})^{4}$.

Take a numerical example to illustrate the economic incentives for litigation funders under English cost-shifting rule. Assume the potential proceeds of a claim are 100,000 Euro (P). The funder supposes that the (S) is $80 \%$, and the contractually determined (R) is $30 \%$. The expected litigation costs $\mathrm{E}(\mathrm{C})$ is 20,000 Euro. And the potential adverse fee is also 20,000 Euro. In this case, $\mathrm{E}\left(\mathrm{M}^{\prime}\right)=(\mathrm{P}) \times(\mathrm{S}) \times(\mathrm{R})=100,000 \times 80 \% \times 30 \%=24,000$. And the $\mathrm{E}(\mathrm{C})=[1-(\mathrm{S})] \times[\mathrm{E}(\mathrm{Cp})+\mathrm{E}(\mathrm{Cd})]=40 \% \times(20,000+20,000)=16,000$, which is lower than $\mathrm{E}\left(\mathrm{M}^{\prime}\right)$. So,

\footnotetext{
${ }^{3} \mathrm{E}(\mathrm{Cp})$ represents litigation costs of the funded litigant.

${ }^{4} \mathrm{E}(\mathrm{Cd})$ represents litigation costs of the opposite litigation party (adverse fees).
} 
in this case, a rational litigation funder will fund the case. However, we should notice that the adverse fees E(Cd) in a case is difficult to predict. Therefore, under English rule, it is not easy to use this equation to make a precise assessment of a future investment.

For the plaintiff. The difference between the economic analysis for the plaintiff's incentive to resort to a third party funder in the UK and that in the U.S. is that we should always consider the adverse fees. And like the analysis under American rule, it is better to divide plaintiffs into three catalogues under English rule. The first two types of plaintiffs are the same with those in the U.S., including impecunious plaintiffs and plaintiffs who are able to cover litigation costs in the case. And the third type is a plaintiff who has money to pay for his/her own litigation costs but cannot afford adverse fees when the case loses. In the following sections, those three types of plaintiffs will be investigated respectively by an economic methodology.

For an indigent plaintiff, by turning to a third party funder, his/her $E\left(M^{\prime \prime}\right)$ is always $>=0$. So, for the first type of plaintiffs, contracting with a funder is always a wise choice. Secondly, for a wealthy plaintiff, like the economic analysis in the U.S., whether the plaintiff decides to resort to a funder depends on whether the final proceeds with TPLF are higher than those generated without TPLF. In summary, E(M') $>E(F)$. Under English cost-shifting rule, that is $(\mathrm{P}) \times(\mathrm{S})-[1-(\mathrm{S})] \times[\mathrm{E}(\mathrm{CP})+\mathrm{E}(\mathrm{Cd})]>(\mathrm{P}) \times(\mathrm{S})-(\mathrm{P}) \times(\mathrm{S}) \times(\mathrm{R})$. Thus, the final result will be $(\mathrm{P}) \times(\mathrm{S}) \times(\mathrm{R})>[1-(\mathrm{S})] \times[\mathrm{E}(\mathrm{Cp})+\mathrm{E}(\mathrm{Cd})]$. In this equation, the variable is the success rate $(\mathrm{S})$ and the adverse costs $\mathrm{E}(\mathrm{Cd})$. For a plaintiff, when a cost-and-benefit analysis is conducted, there are more unpredictable factors under English rule than that under American rule, which are mainly because adverse fees are difficult to foresee.

For the third type of plaintiff, we suppose that resorting to a third party funder will be beneficial under any circumstance. The reason is simple. If the plaintiff wins, he/she can collect a part of recoveries from the judgment or the settlement. On contrary, if the case is not successful, litigation costs and adverse fees will be paid by the funder, and the plaintiff has nothing to lose.

\section{Further Analysis of the Basic Economic Model}

\section{Under What Circumstances the Plaintiff will Resort to TPLF}

The basic economic model has already explained when the funder and the plaintiff are willing to enter into a TPLF contract. One significant finding is that both the plaintiff and the funder are profit maximizers, who will enter into a contract when the expected proceeds are increase by the contract (Shavell, 2004). For each case, whether the funder and the plaintiff will sign a TPLF contract with each other depends on several factors. As indicated in the economic model, such factors may include the prospect of the case and the adverse fees under English rule. In this section, these two factors will be studied respectively.

A good prospect of the case. In the economic model, we can see that from the perspective of a funder, he/she enters into a TPLF contract only if under American rule, $(\mathrm{P}) \times(\mathrm{S}) \times(\mathrm{R})>\mathrm{E}(\mathrm{C})$; and under the English rule, $(\mathrm{P}) \times(\mathrm{S}) \times(\mathrm{R})>[1-(\mathrm{S})] \times[\mathrm{E}(\mathrm{Cp})+\mathrm{E}(\mathrm{Cd})]$. So, it could be found that under these two rules, the factor $(\mathrm{P})$, which demonstrates the success rate of a case is quite important. If other factors remain unchanged, the increase of $(\mathrm{P})$ will result in more proceeds for the funder. From the perspective of the plaintiff, he/she chooses to turn to TPLF only if under American rule, $(\mathrm{P}) \times(\mathrm{S}) \times(\mathrm{R})>\mathrm{E}(\mathrm{C})$; and under English rule, $(\mathrm{P}) \times(\mathrm{S}) \times(\mathrm{R})>[1-(\mathrm{S})] \times$ $[\mathrm{E}(\mathrm{Cp})+\mathrm{E}(\mathrm{Cd})]$. It also suggests that the success rate of a case is in direct proportion to the possibilities that the 
plaintiff will resort to a third party funder.

But the "prospect of a case" is an abstract notion, and it is not easy for the funder to decide whether or not to fund a case just through such a vague concept. Practically, as a professional player in litigation market, the funder has developed a series of selection criterions, which includes, for example, the merits of the case, available evidence, potential risks, the size of the claim, and the likely return (Hodges, Peysner, \& Nurse, 2012). Plenty of literatures show that among these factors, the funder attaches significant importance to the merit of a case (Hodges et al., 2012; de Morpurgo, 2011; Pennell, 2004; U.S. Chamber Institute for Legal Reform, 2009). ${ }^{5}$ For example, the IMF (one of the Australian leading litigation funding companies) generally takes cases with at least a $85 \%$ of chance of success or there are special reasons that the committee thinks justify a deviation from this approach. ${ }^{6}$ And it is also indicated that in general, rational funders prefer to finance cases with chances of success of at least $60 \%$, and a $50 \%$ chance of success is not enough (Hodges et al., 2012). Moreover, the application of rational economics means that funders simply do not fund unmeritorious cases (Hodges et al., 2012).

Adverse fees under the English cost-shifting rule. In the basic economic model, we could find that except for the success rate of a case, adverse fees in a losing claim would be a concern for the third party funder. Empirical studies demonstrate that TPLF develops well in the UK, and the market is expanding rapidly (Veljanovski, 2012; Hodges et al., 2012). And there is no evidence showing that the development of TPLF is deterred by the unpredictability of adverse fees. In practice, funders could require their clients to cover the risk of adverse fees by way of obtaining of ATE (after-the-event) insurance. ${ }^{7}$ In this respect, professional litigation funders may also be capable of externalizing investment risks through a portfolio of funding schemes.

In fact, to what extent the funder should cover adverse fees under the English rule of "losers pay" has been debated for long. It is true that this issue could be provided in the TPLF agreement. But what we discuss here is if the extent of liability of adverse fees is not provided in the TPLF contract, what should it be? As a non-litigation party, should the funder, who has not expressly agreed to meet any adverse costs in the funding agreement, be liable for such fees if his client loses the claim? In this regard, the Arkin principle stating that the funder's liability to pay the adverse costs should be capped to the extent of the level of funding that the funder provided to his/her client previously is established ${ }^{8}$. But Lord Jackson's final report opposed the Arkin Principle, and recommended that third party funders should be fully exposed to adverse fees of litigation which they fund. ${ }^{9}$ And the extent of the funder's liability should be a matter for the discretion of the court on a case-by-case basis. ${ }^{10}$ Generally, Lord Jackson supposed that a funder's potential liability should not be limited by the extent of his investment in the

\footnotetext{
${ }^{5}$ See for example, Hodges et al., 2012 (stating that a detailed assessment by the funder includes the legal merits of the case, p. 2; and it also states that in England and Wales the key consideration by a funder before funding a case is the merits of a given case, $\mathrm{p}$. 41). And also see Marco de Morpurgo, 2011, p. 370 (stating that before making an investment, the funder will check the merits of a case); see also Kevin Pennell (2004), pp. 494-496 (stating that in order to recoup the investment, funders prefer cases with merits); See U.S. Chamber Institute for Legal Reform, 2009, pp. 5-7 (stating that a funder will select cases that will likely to recoup their investment, which could avoid cases entirely without merits to be commenced).

6 See Corporate Governance Manual of IMF (24 October 2012), para 4.18.6, available at http://www.imf.com.au/docs/default-source/site-documents/corporategovernancemanual201210248F070D8E90DB

${ }^{7}$ In fact, lawyers taking cases on conditional fee agreements may also have ATE in place to shield from the risk of adverse fees. See Christopher Hodges et al, Litigation Funding: Status and Issues (2012), p. 70.

${ }^{8}$ Arkin v Borchard Lines Ltd [2005] EWCA Civ 655. For example, if a litigation funder invests $£ 1$ million in an unsuccessful claim, he would only be liable for up to an additional $£ 1$ million of adverse costs.

9 Jackson's final report (2009), p. 123.

10 Ibid.
} 
case, because a limited liability of adverse fees is unjust to the opposing party (whose costs may not be covered), and to the client (who may still be liable for the costs that have not been covered by the funder). ${ }^{11}$ Actually, in Arkin, the funder just partially financed the litigation costs (including the disbursement of expert witness and the cost of organizing the documents), which cost $£ 1.3$ million. In this case, it is hard to imagine that the funder should be fully liable for the adverse fees over $£ 6$ million, which is, obviously, disproportionate (Veljanovski, 2012). But if a litigation funder funds all of the litigation costs of an unsuccessful case, should he/she be fully liable for the adverse costs? In Arkin, the court also indicated that the Arkin principle could still be applied to a fully-funded case. ${ }^{12}$

In this respect, we suppose that Lord Jackson's recommendation should be adopted. It is generally because that compared to individual litigation parties, litigation funders may be more capable of externalizing investment risks through a portfolio of cases, and they can diminish the risk of adverse fees through insurance product (e.g., ATE insurance). On contrary, impecunious plaintiffs and defendants may not have many opportunities to externalize such risks. ${ }^{13}$ Therefore, if the Arkin principle was generally applied, it would create an uneven playing field leaning to the side of litigation funders.

\section{Externalities Brought by the Use of TPLF}

Access to justice. TPLF is able to facilitate the access to justice for indigent litigants by providing financial help for them. On top of those "poor" litigants, TPLF is also beneficial to risk-averse "non-poor" ones. It may be inferred that TPLF, which increases the level of equality, produces the external effect of increasing all individuals' utilities in term of facilitating the access to justice (Shavell, 2004). Under the classical utilitarian ideology of social welfare, the overall level of social welfare is proportionate to the level of each individual's utility (de Morpurgo, 2011). Regardless of the classical utilitarian ideology which just values the sum, the distribution of utilities indeed matters. More equal distribution of utility may be superior to less equal distributions (Shavell, 2004). In light of that, the introduction of TPLF has a positive external effect that would be helpful to increase the overall social welfare (de Morpurgo, 2011).

Deterrence. Besides the facilitation of access to justice, the potential deterrence effect produced by the TPLF system is significant. If the potential injurers were aware of the fact that the plaintiffs have no sufficient financial resources to support the litigation, they would engage in their harmful activities more unscrupulously because they have little fear that the impecunious plaintiffs will spend lots of money to commence a lawsuit against them. In this case, the cost of a harmful behavior is too low to deter potential injurers. However, the introduction of TPLF will change this situation. Even though the plaintiff does not actually resort to a funder, the potential financial support provided for the needy plaintiffs may have deterrence effect to potential wrongdoers.

The deterrent effect will be enhanced in common law jurisdictions which apply the doctrine of stare decisis ${ }^{14}$, under which a former judgment has precedent value for future ones. In terms of the economic theory of litigation,

\footnotetext{
11 Ibid.

12 Arkin v Borchard Lines Ltd [2005] EWCA Civ 655.

13 Professional litigation funding may lose investment in one case, but win money in others, so the risk of losing money could be diminished by a series of investments. But for plaintiffs and defendants, they are not frequent litigation player. Therefore, if they lose in one case, it may be difficult to gain in other cases. In this regard, plaintiffs and defendants are more "vulnerable" than professional litigation funders.

14 "Stare decisis" is an latin word which means the precedents have to be followed by the cases judged in the future.
} 
such doctrine may save the general litigation costs (including the judicial resources as well as the personal expenses in litigation) to a certain degree. The TPLF may sponsor cases with high social or monetary value, which could be established as a precedent to discourage wrongdoers from conducting misbehaviors.

Potential increase of the overall volume of litigation. Counterarguments contend that allowing TPLF will result in the filing of more lawsuits (Robin, 2011). Potential lawsuits, which would otherwise be dropped because of costly legal expenses and high litigation risks, would be filed with the financial assistance from a third party funder (Lyon, 2010). But it has been asserted that even though the general volume of litigation does increase, why do we consider it as a negative signal (Sebok, 2011)? If the funded lawsuits are not frivolous and are based on merits, the increase of those cases would not be a bad thing, because it means that more illegal behavior could be corrected and wrongdoers could be held liable for wrongdoings (Pennell, 2004).

TPLF is a relatively new approach to finance civil litigation, there is a dearth of data to demonstrate its effects on litigation volume. The first published article on empirical study of TPLF was accomplished by David Abrams and Daniel L. Chen in 2012, where the application of TPLF in Australia was analyzed from the perspective of empirical study. This article found that the filing of lawsuits has indeed increased in those jurisdictions where TPLF was allowed (Abrams \& Chen, 2012). While in those jurisdictions not using TPLF, they noticed a decline in the amount of lawsuits (Abrams \& Chen, 2012). However, it has also been challenged that the empirical study was conducted in Australia where the TPLF was largely applied in insolvency cases and class actions (Lyon, 2010). However, in other countries where TPLF is also adopted (e.g., the U.S.), the primary focus of such mechanism was not like that in Australia (Lyon, 2010). ${ }^{15}$ So, the effects of the application of TPLF observed by David Abrams and Daniel L. Chen in their article could not simply be duplicated in other jurisdictions (e.g., the U.S.).

The question about the overall volume of litigation could also be analyzed by Shavell's (1982) theory. In Shavell's viewpoint, if the general benefits and potential deterrence effect outweigh litigation costs, TPLF is socially desirable (Shavell, 1982). Otherwise, it is undesirable. In light of this theory, the increase of lawsuits after the introduction of TPLF could not be simply considered as a negative signal. The question whether it is socially desirable should depend on the evaluation of its total costs and benefits, as indicated before.

Frivolous and unmeritorious suits. The basic economic model shows that litigation funders consider the merits of a case as the most important criterion before making an investment (Shavell, 1982). Funders will engage in due diligence when evaluating the potential investment and are likely to choose those lawsuits with good prospect of success. ${ }^{16}$ The due diligence conducted by the funders could be regarded as a filter to weed out frivolous and unmeritorious claims, which is similar to the motivation of attorneys in contingency fee agreement.

\footnotetext{
${ }^{15}$ For example, contingency fee arrangements (funding by lawyers) are allowed in the U.S., but not in Australia. Therefore, without the introduction of TPLF, impecunious plaintiffs in Australia have no other effective alternatives to commence litigation, while in the U.S., they could be able to solve funding difficulties through contingency fee arrangements. What we suppose is that in the U.S., there have been other funding alternatives to remove the funding obstacle, so the permission of TPLF may not lead to an obvious increase in case volume, which is different from that in Australia.

${ }^{16}$ As some data presented, the selection of litigation to be funded is quite stringent. For example, in Australia, the largest litigation funding company (IMF) only funded 5\% among the funding applications during 2001 to 2010. Similarly, in the U.S., the Juridica Capital Management only funded 6\% of the cases considered. See RAND ICJ conference in Washington D.C. Conference: Alternative litigation finance in the U.S.- where are we and where are we headed with practice and policy?, Washington, D.C., May 20-21, 2010.
} 
Generally, the potential interest in recovery would prevent attorneys from accepting frivolous cases on a contingent basis (U.S. Chamber Institute for Legal Reform, 2009). Actually, contingency fee attorneys can diminish risk through a mix paid and contingency cases, however, third party funders depend more on an accurate assessment of the value of cases and risks associated with them (Lyon, 2010). Therefore, the evaluation of the value of cases by the third party funders may surpass that of most of attorneys (Molot, 2009). David Abrams and Daniel L. Chen (2012) studied the funding investment in IML and found that it was true that the funded cases grew even riskier over the past several years. But there is no evidence in their article to show that third party funders will accept truly frivolous or unmeritorious cases because there are few possibilities to recoup their investment through them.

How to achieve social desirability of TPLF: Through regulations. Shavell indicated that

Litigation is socially desirable when the deterrence benefit from litigation exceeds the expected cost of litigation. A lawsuit is privately desirable from the plaintiff's perspective when the expected award exceeds the expected cost of litigation to the plaintiff. Thus, the private incentive to litigate diverges from the social incentive. (Shavell, 1982, pp. 333-339)

We could find from Shavell's theory that the private individual's standpoint diverges from that of the society as a whole. In context of TPLF, the divergent incentives among the plaintiffs, the society and the third party funders become more complex. The basic economic model demonstrates that both the funder and the funded party are profit-driven. They choose to enter into a TPLF contract only if the TPLF could bring more benefits (Shavell, 1982). Even though third party funders may not accept truly frivolous or unmeritorious cases through which it is difficult to recoup their investment (Shavell, 1982), it still could not prove that the standpoint of the funder is in line with the social desirability. ${ }^{17}$ Furthermore, the funder could externalize and eliminate risks if this case portfolio is strong enough. By this way, the litigation funder may keep a cost-and-benefit balance. Litigation funding indeed opens the door for adventurous funders. It is possible that a funder who has sufficient assets could gamble on a case with extremely high monetary proceeds but a lower prospect of success. As a matter of fact, there is a relationship between size and merits of a case (Hodges et al., 2012). If a case has fewer merits, its sufficient size may offset its lower chances of success to achieve an acceptable return (Hodges et al., 2012). Due to that, the self-regulation by the litigation funding market does not always work well. As a special market, litigation funding should be subject to certain regulations ${ }^{18}$ because public products (the publicly-funded court system) are also consumed in litigation. ${ }^{19}$

\section{Conclusion}

This article analyzed the working mechanism of TPLF and the roles of parties (the funder and the funded

\footnotetext{
${ }^{17}$ For example, a funder may prefer to accept an early settlement to recoup his investment, but from the perspective of social value, some cases demonstrating public interest might be better to be adjudicated other than be settled early.

${ }^{18}$ In fact, in countries permitting the use of TPLF, there are regulations on it. (e.g., ethical code for litigation funder, the prohibition of frivolous cases) For example, the Solicitors Regulation Authority Code of Conduct 2011 is used in the UK to regulate the behaviors of litigation funders. Available at http://www.sra.org.uk/solicitors/handbook/code/content.page.

${ }_{19}$ For example, the strict prohibition of frivolous cases, strike suits, and actions without merits. And the relationship between funders, clients and lawyers should be regulated in order to avoid moral risks. Litigation is proceeded in the court which is a public product mainly financially relying on the state budget and tax revenue. Therefore, the trial on a case consumes the public product.
} 
party) in a TPLF contract through an economic way. Generally, we support the use of TPLF. And through the basic economic model, we can find that concerns about frivolous and unmeritorious cases could be solved through the litigation market itself, because the funder would conduct a cost-and-benefit analysis prior to entering into a TPLF contract. But to achieve the social desirability of TPLF, regulations of it are still needed.

\section{References}

Abrams, D. S., \& Chen, D. L. (2012). A Market for justice: A first empirical look at third party litigation funding. Journal of Business Law, 15, 1075. Retrieved from https://scholarship.law.upenn.edu/jbl/vol15/iss4/4

Calihan, R. B., Dent, J. R., \& Victor, M. B. (2004). The role of risk analysis in dispute and litigation management. American Bar Association 27th Annual Forum on Franchising. Retrieved from http://www.litigationrisk.com/Paper\%20on\%20Risk\%20Analysis\%20for\%20ABA\%20Forum\%20on\%20Franchising.pdf

de Morpurgo, M. (2011). A comparative legal and economic approach to third party litigation funding. Cardozo Journal of International and Comparative Law, 19, 343.

Hodges, C., Peysner, J., \& Nurse, A. (2012). Litigation funding: Status and issues. Oxford Legal Studies Research Paper No. 55/2012. Retrieved from http://ssrn.com/abstract=2126506 or http://dx.doi.org/10.2139/ssrn.2126506

Kalajdzic, J., Cashman, P., \& Longmoore, A. (2013). Justice for profit, a comparative analysis of Australian, Canadian and U.S. third party litigation funding. The American Journal of Comparative Law, 61(1), 93-148.

Lyon, J. (2010). Revolution in progress: Third party funding of American litigation. UCLA Law Review, 58, 571-590.

Molot, J. T. (2009). A market in litigation risk. University of Chicago Law Review, 76(1), Article 13. Retrieved from https://chicagounbound.uchicago.edu/uclrev/vol76/iss1/13

Pennell, K. (2004). On the assignment of legal malpractice claims: A contractual solution to a contractual problem. Texas Law Review, 82, 481, 494-496.

Robin, P. H. (2011). Third party financing of litigation. Northern Kentucky Law Review, 38, 673-682.

Sebok, A. J. (2011). The inauthentic claim. Vanderbilt Law Review, 64, 61-68.

Shavell, S. (1982). The social versus the private incentive to bring suit in a costly legal syste. Journal of Legal Studies, 11(2), 333-340.

Shavell, S. (2004). Foundations of economic analysis of law. Harvard: Harvard University Press.

Thomson Reuters. (2011). New York City bar gives thumbs up to litigation-funding. Retrieved from http://newsandinsight.thomsonreuters.com/Legal/News/2011/06_-_June/New_York_City_Bar_gives_thumbs_up_to_ litigation-funding/

U.S. Chamber Institute for Legal Reform. (2009). Selling lawsuits, buying trouble: Third party litigation funding in the United States. Retrieved from http://www.instituteforlegalreform.com/sites/default/files/thirdpartylitigationfinancing.pdf

Veljanovski, C. (2012). Third party litigation funding in Europe. Journal of Law, Economics \& Public Policy. Retrieved from http://ssrn.com/abstract=1971502

Vogenauer, C. H. S., \& Tulibacka, M. (2010). The cost and funding of civil litigation. Oxford and Portland, Oregon: Hart Publishing. 